\title{
Plasminogen activator in the human prostate
}

\author{
R. C. KESTER \\ From the Department of Surgery, Dundee Royal Infirmary
}

SYNOPSIS The distribution of plasminogen activator in fresh human prostatic tissue has been studied, using a histological technique. The vascular endothelium consistently showed fibrinolytic activity while inconstant and lesser activity arose from the epithelial cells of glands and ducts. Increased epithelial activity was often accompanied by evidence of trauma. Activity of the secretions was insignificant. The source of the fibrinolytic activity of blood in prostatic disease and of the seminal fluid remains uncertain, and cannot yet be ascribed to the prostatic epithelium.

The blood of man is rich in plasminogen, the precursor of plasmin, a fibrinolytic protease (Astrup, 1956). Many tissues, including the prostate (Rasmussen and Albrechtsen, 1960), contain substances which can activate plasminogen and thus initiate fibrinolysis. Both the excessive fibrinolysis seen in the blood of some patients with prostatic disease (Jürgens and Trautwein, 1930; Tagnon, Whitmore, Schulman, and Kravitz, 1953) and the normal fibrinolytic activity of seminal fluid (Von Kaulla and Shettles, 1953) have been attributed to the release of such activators from the prostatic epithelium.

However, using a histological technique for the identification of plasminogen activator in tissues, Todd (1961) has found activator to be concentrated only in the blood vessels of most tissues, including the prostate, where the epithelium and secretions seemed inactive. In his experiments, however, postmortem tissues were used so that if any of the activator in the prostate is labile it might have decayed before the tests were made. To see whether the prostatic epithelium contains any such labile activator, a series of fresh, surgically removed prostate glands were examined by the histochemical technique.

\section{METHOD}

Blocks of tissue were taken from 25 glands immediately after enucleation prostatectomy, and immersed in tissue culture medium no. 1991 (Paul, 1965). In three cases there was a carcinoma; the remaining 22 glands showed benign fibromuscular glandulo-cystic hyperplasia. The blocks of tissue were stored in the culture medium at $4^{\circ} \mathrm{C}$ for one to 12 hours, until an opportunity arose to

${ }^{1}$ Glaxo Laboratorics Ltd.

Received for publication 19 December 1968. 'quick-freeze' them by placing them in small polythene bags, then plunging the bags into dry ice-acetone mixture. The bags were usually stored in the deep-freeze at $-30 \mathrm{C}^{\circ}$ for periods up to 17 days. However, if sections were to be made immediately, the tissues were frozen directly on to the cryostat microtome chuck.

Tissue sections of 7 to $8 \mu$ were applied to coverslips, and allowed to dry at room temperature for $\mathbf{3 0}$ minutes before making the histological preparations. This histochemical technique was that of 'fibrinolysis autography' (Todd, 1964). A film of bovine fibrin, rich in plasminogen, was applied to the unfixed dried sections, and the preparations were incubated at $37^{\circ} \mathrm{C}$ for 15,30 , and 60 minutes. Two preparations were taken at the end of each period, fixed, stained and mounted for microscopy. Wherever the section contained activator, the plasminogen in the overlying fibrin was converted to plasmin, and the fibrin was digested. Microscopic examination of these preparations now shows the areas of digestion as pale gaps in the fibrin background, and these may be related topographically to structures in the overlying section.

\section{SCORING FOR FIBRINOLYTIC ACTIVITY}

Adjacent sections were stained with haematoxylin and eosin, and the appearances of these were compared with the autographs and with the surgical pathologist's report made on the remainder of the gland to ensure that a representative sample had been tested.

The degree of fibrinolytic activity of blood vessels, glands, ducts, and secretions at 15,30 , and 60 minutes $O$ was assessed, using a system of grading modified from that of Pandolfi, Nilsson, Robertson, and Isacson (1967). ?

The activity was scored for each preparation as follows: activity detectable with naked eye, 3 ; activity only detectable using a $10 \times$ magnifier, 2; and activity only detectable microscopically at magnification $\times 100,1$. For each tissue component, the arbitrary units derived from the six samples were summed, and this value represents the fibrinolytic activity for that component (see Table). 


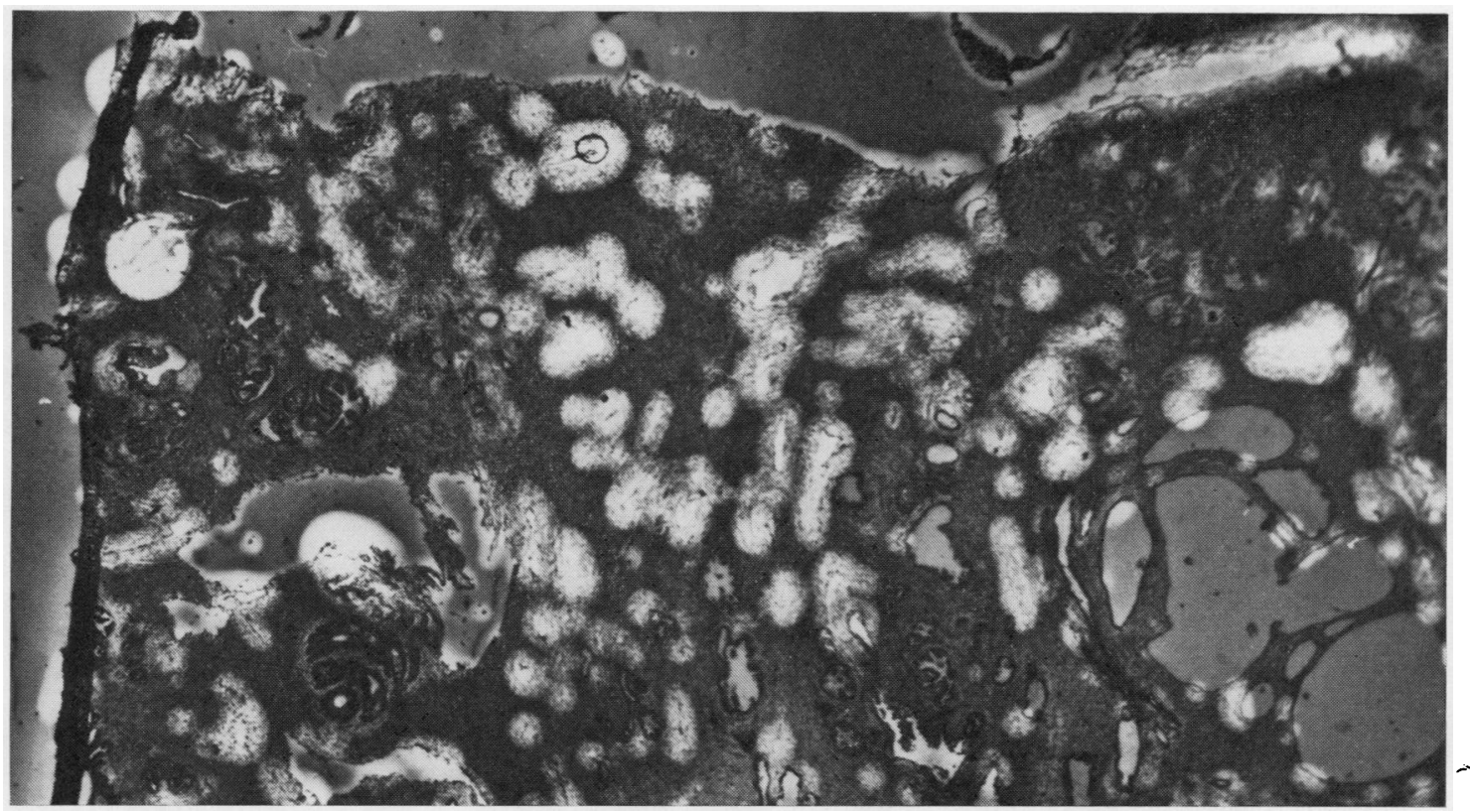

FIG. 1. Fibrinolysis autograph of prostatic tissue showing striking fibrinolytic activity consistently related to the blood vessels. Note the areas of lysis occurring at the edge of the section. $\times 16$.

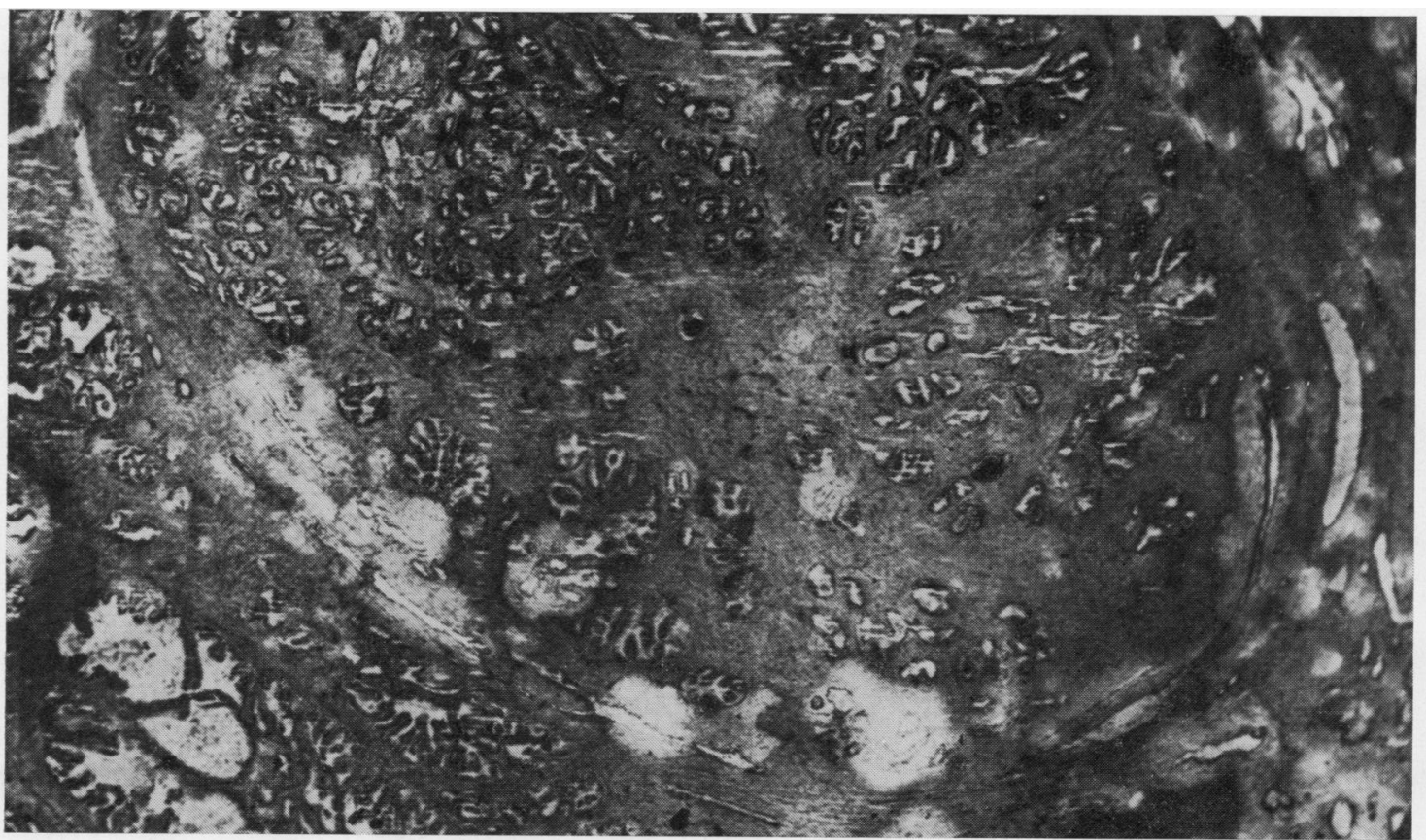

FIG. 2. Autograph showing zones of lysis arising from blood vessels in the fibromuscutar stroma surrounding groups of inactive prostatic glands. $\times 16$. 


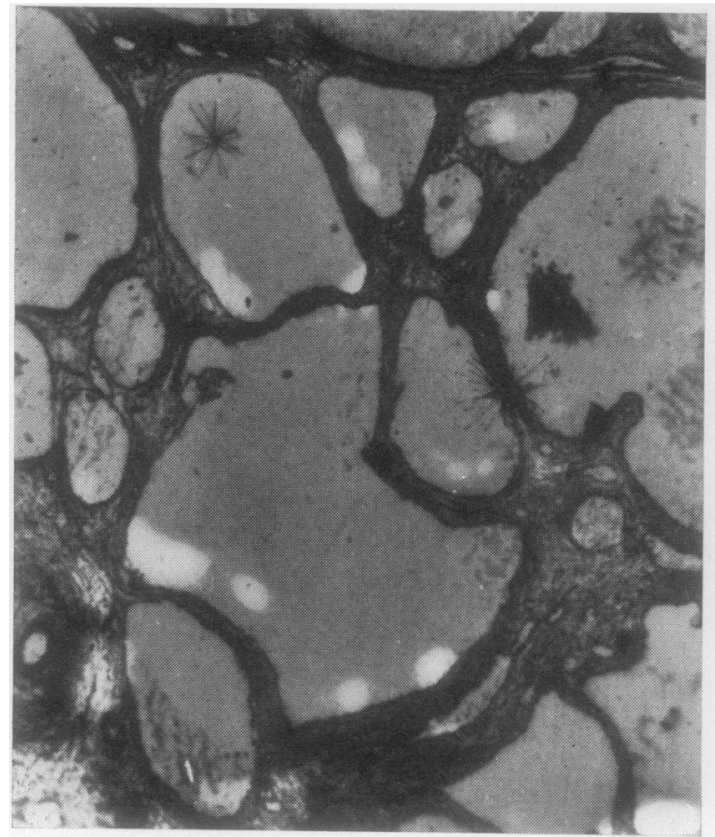

FIG. 3. Fibrin-slide preparation showing areas of digestion arising haphazardly at various sites from the glandular epithelium. Several isolated areas of fibrinolysis occur within the secretions. $\times 20$.

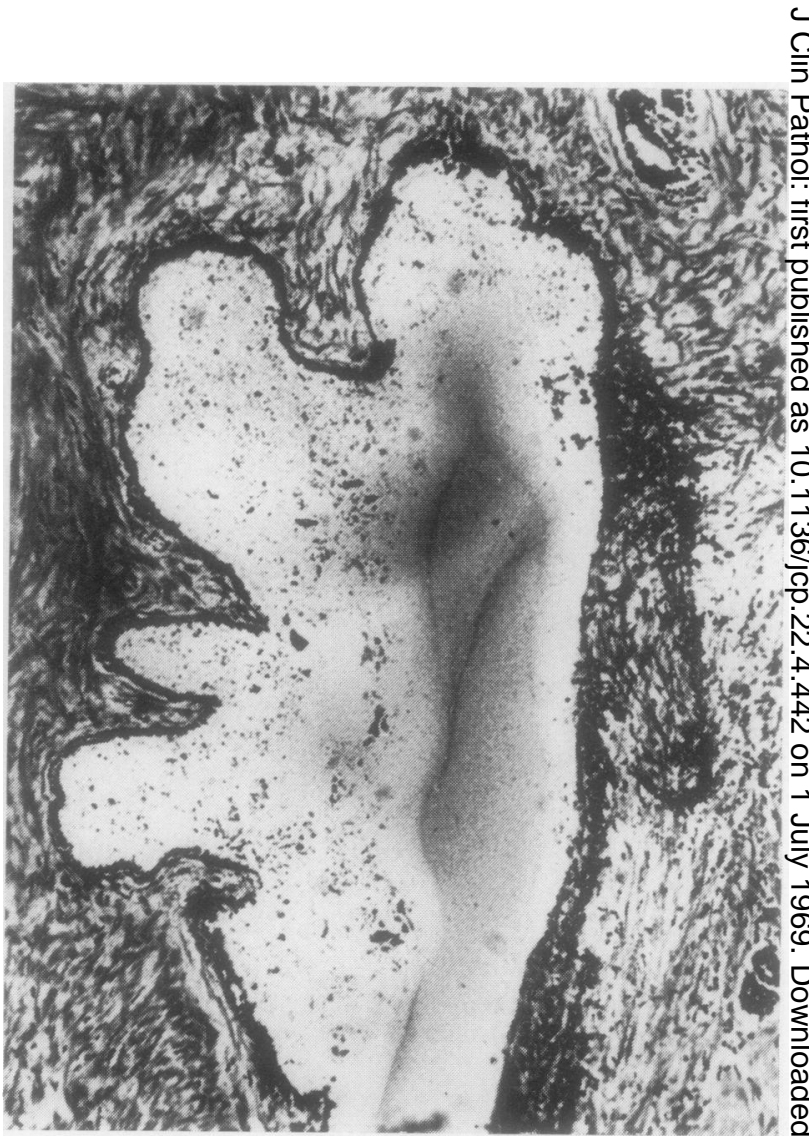

FIG. 4.

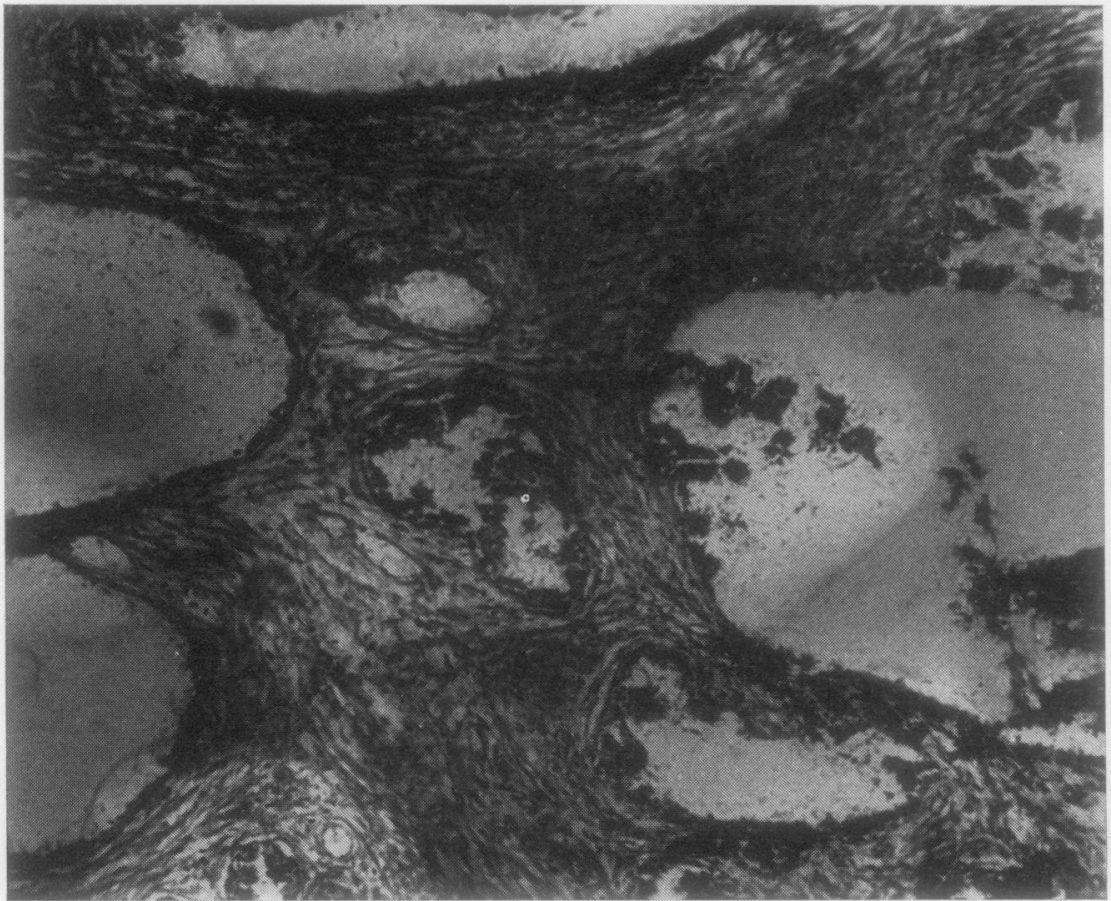

FIG. 5.
FIG. 4. Fibrinolysis 을 arising from the epithelium $>$ lining a prostatic duct. Maximum digestion related to detached epithelial cells. $\times 100$.

FIG. 5. Fibrinolytic mainly around shed epithelial cells within the ducts. $\times 100$. activity concentrated 


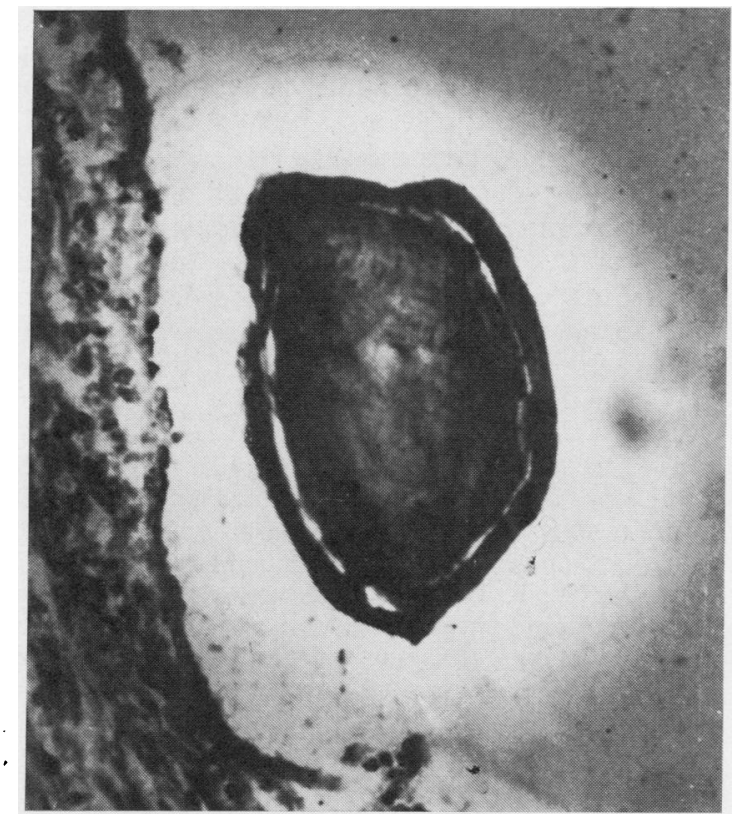

FIG. 6. Autograph showing a prostatic concretion surrounded by a zone of fibrinolysis. $\times 168$.

\section{RESULTS}

As before, fibrinolytic activity was always seen in relation to the blood vessels (Fig. 1). Vascular activity was most striking in the fibromuscular stroma surrounding groups of glands (Fig. 2). The adenomatous nodules were consistently ringed by foci of activity, where the vessels were sinuses often consisting only of endothelium.

Fibrinolysis of a lesser degree than that around vessels was seen in relation to the glands (Fig. 3) and ducts. The activity from these structures was infrequent and of haphazard distribution, most of the glands and ducts being inactive. The lysis was most pronounced where the epithelial lining was disrupted, and was proportional to the number of detached cells (Figs. 4 and 5).

Secretion within the glands (Fig. 3) or ducts was seldom active and lysis from it was seen in only three autographs. In a unique instance, activity was related to an inspissated mass of secretion (Fig. 6).

There was often increased activity at the edges of the section, where the tissue was most damaged. No fibrinolysis was seen related to collections of polymorphs. There was no difference between the activity of adenomatous and carcinomatous sections.

\section{DISCUSSION}

It has been shown by Astrup and Permin (1947) that the fibrinolytic activity in human tissues is due to their ability to activate plasminogen. Prostatic tissue is rich in substances which can activate plasminogen (Rasmussen and Albrechtsen, 1960), and it has been assumed that the increased fibrinolysis noted in prostatic disease (Jürgens and Trautwein, 1930; Tagnon et al, 1953), and in prostatic surgery

TABLE

DISTRIBUTION OF FIBRINOLYTIC ACTIVITY FROM PROSTATIC TISSUE COMPONENTS (ARBITRARY UNITS)

\begin{tabular}{|c|c|c|c|c|c|}
\hline Case No. & Overall Activity & Vascular & Glands & Ducts & Secretion \\
\hline $1^{1}$ & 12 & 12 & 4 & 4 & 0 \\
\hline 2 & 6 & 6 & 0 & 0 & 0 \\
\hline 3 & 10 & 10 & 4 & 2 & 0 \\
\hline 4 & 12 & 12 & 4 & 0 & 0 \\
\hline 5 & 16 & 16 & 10 & 0 & 0 \\
\hline $6^{1}$ & 12 & 12 & 4 & 0 & 0 \\
\hline 7 & 16 & 16 & 0 & 0 & 0 \\
\hline 8 & 16 & 16 & 0 & 0 & 0 \\
\hline 9 & 16 & 16 & 12 & 12 & 0 \\
\hline 10 & 16 & 16 & 8 & 8 & 0 \\
\hline 11 & 16 & 16 & 8 & 8 & 6 \\
\hline 12 & 14 & 14 & 8 & 4 & 0 \\
\hline 13 & 16 & 16 & 10 & 6 & 0 \\
\hline 14 & 12 & 12 & 4 & 0 & 0 \\
\hline 15 & 18 & 18 & 8 & 0 & 2 \\
\hline 16 & 16 & 16 & 4 & 0 & 0 \\
\hline $17^{1}$ & 8 & 8 & 6 & 0 & 0 \\
\hline 18 & 16 & 16 & 8 & 0 & 0 \\
\hline 19 & 16 & 16 & 8 & 8 & 0 \\
\hline 20 & 16 & 16 & 10 & 4 & 0 \\
\hline 21 & 16 & 16 & 8 & 0 & 0 \\
\hline 22 & 6 & 6 & 2 & 0 & 0 \\
\hline 23 & 10 & 10 & 0 & 0 & 0 \\
\hline 24 & 16 & 16 & 4 & 4 & 0 \\
\hline 25 & 10 & 10 & 2 & 0 & 0 \\
\hline
\end{tabular}

${ }^{1}$ Denotes carcinoma 
(Lombardo, 1957; Urlus, 1962), is due to the release of this activator into the blood stream (Fearnley, 1965). It has also been assumed that this activator is of epithelial origin and identical with the semenliquefying protease (Huggins and Neal, 1942).

In the light of these and othur observations (Huggins and Vail, 1943; Tagnon, Schulman, Whitmore, and Kravitz, 1952; Scott, 1956), it is surprising that, with the histological technique, prostatic epithelium shows only slight ability to activate plasminogen. The present experiments do not support the view that fibrinolysis in prostatic disease could come from the glandular epithelium, and confirm the previous finding (Todd, 1961) that the bulk of the fibrinolytic activity of normal and carcinomatous prostatic tissue arises from the blood vessels. However, none of the cases in the present series showed a bleeding tendency, and until tissue from such haemorrhagic cases can be examined by fibrinolysis autography, the possibility remains that some types of prostatic epithelium, especially in carcinoma, may have a greatly increased activator content. It may be that bovine fibrin and plasminogen are unsuitable substrates for the semen-liquefying factor, and that if fibrinolysis autographs are prepared using human fibrin, more activity will be detected in epithelium. To date, this has not been found to be the case.

It is equally likely that the bleeding in cases of metastatic prostatic cancer is a manifestation of disseminated intravascular coagulation (Swan, Wood, and Daniel, 1957; Rapaport and Chapman, 1959). It is now known that the prostate is rich in thromboplastin (Benzer, Blümel, and Piza, 1962), which may be released into the circulation when the cancer or its metastases are damaged or necrotic. Fibrinolysis would then follow as a secondary phenomenon.

The results also cast doubt on previous assumptions about plasminogen activator in semen. When human semen is ejaculated, it coagulates then liquefies spontaneously. The coagulum is formed when a fibrinogen-like protein secreted by the seminal vesicles is acted upon by a clotting enzyme from the prostate (Mann, 1964). Coagulation is followed within about 20 minutes by liquefaction of the clots by a plasmin-like enzyme said to come from the prostate (Huggins and Neal, 1942), although there is no direct evidence that this enzyme has come from prostatic epithelium. A semen-liquefying $\underset{\overrightarrow{\mathrm{S}}}{\overrightarrow{\mathrm{S}}}$ 'fibrinolysin' has certainly been found in fluid obtained by prostatic massage (Huggins and Neal, $\frac{\square}{0}$ 1942) but the reason for supposing that it came from the gland, rather than from the seminal vesicles, is not clear. There is evidence in the autographs to suggest that epithelium is more active when damaged ${ }^{\text {os }}$ and desquamated, so that prostatic massage may $\vec{\circ}$ enhance the fibrinolytic activity of the secretory apparatus by the trauma it causes.

I wish to express my warm gratitude to $\operatorname{Dr}$ A. S. ? Todd, who has directed my studies, and I wish to thank N Professor D. M. Douglas for laboratory facilities, Mr + Stanley Soutar for access to biopsy material from his cases, Mr W. F. Walker for his constructive criticism, $N$ Mr Tom King for the photomicrographs, Mrs Frances 을 Firth for typing the script, and the Board of Manage- ment, Dundee General Teaching Hospitals, for $a$ research grant.

\section{REFERENCES}

Astrup, T. (1956), Blood, 11, 781.

- and Permin, P. M. (1947). Nature (Lond.), 159, 681.

Benzer, H., Blümel, G., and Piza, F. (1962). Wien, klin. Wschr. 74,601 .

Fearnley, G. R. (1965). In Fibrinolysis, p. 131. Edward Arnold, London.

Huggins, C., and Neal, W. (1942). J. exp. Med., 76, 527.

$\longrightarrow$, and Vail, V. C. (1943). Amer. J. Physiol., 139, 129.

Jürgens, R., and Trautwein, H. (1930). Dtsch. Arch. klin. Med., 169, 28.

Lombardo, L. J., Jr. (1957). J. Urol. (Baltimore), 77, 289.

Mann, T. (1964). In The Biochemistry of Semen and of the Male Reproductive Tract, 2 nd ed., p. 175. Methuen, London.

Paul, J. (1965). Cell and Tissue Culture, 3rd ed., p. 90. Livingstone, Edinburgh and London.

Pandolfi, M., Nilsson, I. M., Robertson, B., and Isacson, S. (1967). Lancet, 2, 127.

Rapaport, S. I., and Chapman, C. G. (1959). Amer. J. Med., 27, 144. Rasmussen, J., and Albrechtsen, O. K. (1960). Scand. J. clin. Lab. Invest., 12, 261.

Scott, E. van Z. (1956). J. Urol. (Baltimore), 75, 116.

Swan, H. T., Wood, K. F., and Daniel, O. (1957). Brit. med. J., 음 1,495 .

Tagnon, H. J., Schulman, P., Whitmore, W. F., and Kravitz, S. C. $\frac{D}{O}$ (1952). J. clin. Invest., 31, 666.

_- Whitmore, W. F., Schulman, P., Kravitz, S. C. (1953). Cancer (Philad.), 6, 63 .

Todd, A. S. (1961). On the Fibrinolytic Activity of Tissue. MD Thesis, University of Durham.

- (1964). Brit. med. Bull., 20, 210.

Urlus, J. H. L. (1962). J. int. Coll. Surg., 38, 38.

Von Kaulla, K. N., and Shettles, L. B. (1953). Proc. Soc. exp. Biol. (N.Y.), 83, 692 